$$
\begin{gathered}
\text { 胆道外科と感染 } \\
\text { 一とくにェンドトキシン血症の発来について一 }
\end{gathered}
$$

日本医科大学第 1 外科学教室（主任教授：代田明郎）

足立憲 治

\title{
THE EFFECT OF ENDOGENOUS ENDOTOXIN ON OBSTRUCTIVE JAUNDICE
}

\section{Kenji ADACHI}

The First Department of Surgery, Nippon Medical School

(Director: Prof. Akio Shirota)

䋈引用語：胆道感染症, 胆石症, 急性閉塞性化膿性胆管炎 (AOSC), 閉塞性黄疸, 内因性エンドトキシン

\section{I はじめに}

胆道外科疾患々者の数は近年増加の一途をたどってい るが，その手術成績はいまだ満足すべきものではなく， とくに胆道感染が今日の胆道外科手術成績向上を阻害し ている最む大きな要因の 1 つである.

今回, 福島市で行われた第15回本学会総会での“消化 器外科と感染” と題するシンポジウムに際して発表の機 会を与兄られ, 胆道感染症の現況について発言, 討論し たが，紙面の制約もあるので本稿では，(1)わが教室に 扣ける胆石症手術成績の变遷と死因の検討. (2) 胆道感 染のうちでも最も重篤な急性閉塞性化膿珄胆管炎（以下 AOSC と略す）の自験例，全国集計例についての治療 成績叔よびその死因についての検討. (3) 閉塞性黄疸に みられる腸管内細菌由来の内因性エンドトキシン血症の 発来とその治療について述べてみよう。

\section{II 成}

\section{1. 胆石症患者の手術成繶と死因についての検討}

胆石症患者の手術例数は近年増加の一途をたどり, 教 室に招いても，昭和 20 年から昭和 54 年末までの 25 年間を 便宜上 3 期に分けてみると，最近の約 11 年間では 1,375 例と前 2 期の 231 例，773例と較べて著しく増加している 反面，その死亡率は $4.8 \% ， 1.3 \% ， 0.8 \%$ と減少の一途 をたどっている.しかしながらその死亡率を急性期と慢

* 第15回日消外会総会シンポ 1 消化器外科と感染

\begin{tabular}{|c|c|c|c|c|}
\hline \multicolumn{2}{|c|}{ 手微成蜩 年度 } & $\begin{array}{l}\text { 昌和 } \\
20 \text {-31年 }\end{array}$ & $\begin{array}{l}\text { 昭 和 } \\
32 \text { - } 43 \text { 年 } 3 \text { 月 }\end{array}$ & 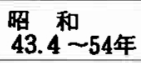 \\
\hline \multirow{3}{*}{ 急性 } & 例 数 & 63 & 214 & 214 \\
\hline & 死 亡 & 7 & 7 & 8 \\
\hline & 死亡事 & $11.19 \%$ & $3.3 \%$ & 3.796 \\
\hline \multirow{3}{*}{ 慢性 } & 例 数 & 168 & 559 & 1161 \\
\hline & 死 亡 & 4 & 3 & 3 \\
\hline & 死亡率 & $2.4 \%$ & 0.5496 & $0.3 \%$ \\
\hline \multirow{3}{*}{ 合計 } & 例 数 & 231 & 773 & 1375 \\
\hline & 死 亡 & 11 & 10 & 11 \\
\hline & 死亡本 & 4.896 & $1.3 \%$ & $0.8 \%$ \\
\hline
\end{tabular}

表 1 胆石症の手術成績の変遷（昭和20～54年）

性期の手術例に分けて比較してみると，細菌性因子の関 与しやすい急性手術例に拈いては，初期の $11.1 \%$ は除外 したとしても, 昭和 32 年以後, 抗生物質の良く研究, 開 発された今日まで $3.7 \%$ 台と一定して居り, 近年の死亡 率低下は慢性期手術に扩ける成績の向上飞依存している のが現況である（表1）.

そこで本症手術による死亡例の死因について検討して みると, 胆汁性腹膜炎, 肝不全, 胆血症, 肝膿瘍, 肝腎 症候群に伴う急性腎不全の如き細菌性因子の関与しやす い続発症が32例中 21 例之, 約 $2 / 3$ を占めて居り，最近の 11年間では術前, 術中, 術後管理方法の向上や麻醉法の 改善により, 心循環不全等の続発症は著しく減少せしめ 
表 2 胆石症手術死亡例の死因（昭和20～ 54 年）

\begin{tabular}{|c|c|c|c|c|}
\hline 死因 年度 & $\begin{array}{l}\text { 照 和 } \\
20 \sim 31 \text { 年 }\end{array}$ & $\begin{array}{l}\text { 昭 和 } \\
\text { 32 43年 } 3 \text { 月 }\end{array}$ & $\begin{array}{l}\text { 昭 } \text { 和 } \\
43.3 \text { 年 }\end{array}$ & 合 計 \\
\hline 胆斗性腹㬺炎 & 3 & 2 & 3 & $8(24.2 \%)$ \\
\hline 肝不全 - 胆血症 & 4 & 1 & 1 & $6(18.8 \%)$ \\
\hline 敗 血 症 & 3 & & & $3(9.1 \%)$ \\
\hline 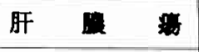 & & & 2 & $2(6.1 \%)$ \\
\hline 急性霄不全 & & & 2 & $2(6.1 \%)$ \\
\hline 急性心細環不全 & 1 & 5 & 2 & $8(24.2 \%)$ \\
\hline 術 後 出 血 & & 1 & & $1(3.0 \%)$ \\
\hline 肺動 眽 栓 塞 & & 1 & & $1(3.0 \%)$ \\
\hline 脳 出 血 & & & 1 & $1(3.0 \%)$ \\
\hline 合 計 & 11 & 10 & 11 & 32 \\
\hline
\end{tabular}

（日医大第 1 外科）

ることが可能であったが, 胆汁性腹膜炎 3 例, 肝不全 1 例, 肝膿瘍 2 例，急性腎不全 2 例 広域抗生物質の上< 研究開発された今日といえども，胆道感染症に続発する 肝腎障害がその死因と密接な関係を有して招り，乙かも このなかには AOSC のような重篤な胆道感染症の少な くなかったことはとくに注目すべき事実で，この胆道感 染こそ今日の胆道外科手術成績を阻害している最も大き な要因の 1 つとい忩る（表 2).

2. AOSC息者の治㾇成縝および死因についての検討

胆道感染症のらち，その治療に最も難涉するのが AOSC であることは諸家の言をまつまでむない，

そこで本症の臨床症状およびその検査成績をみてみる と, 教室例21例では Charcot 3 徵および Reynolds 5 徵 は注ぼ全例にみとめられるばかりでなく，肝腎症候群の ためと理解される乏尿む $90 \%$ に出現して扮り，白血球增 多は全例飞,リムルステストも11例中 5 例に陽性を示 し，紐菌検索に批いても胆汁中よりは全例，血中よりも 11 例中 4 例に陽性例を認めた。

また，昭和54年 9 月わが教室で主催した胆道外科研究 会に際して行った本邦全国集計472例についてみると， Charcot 3徵は教室例と同様涪高頻度に出現していたが， Reynolds 5 徵は低值にとどまった。これは本症診断基 準に関し各施設で多少のばらつきがあったためと考えら れる。また白血球增多およびリムルステスト陽性例は約 2/3を占め，細菌培養に招いても胆汁のみならず血液中 からも多数の陽性例を認めている（表 3 ）.

そこで本症の原因と治療成績をみてみると，教室例，
表 3 急性閉塞性化膿性胆管炎患者の統計的観察 一臨床症状と検查成績—

\begin{tabular}{|c|c|c|c|}
\hline & 日本医大第 1 外科 & 本邦全国集計 \\
\hline \multicolumn{2}{|r|}{ 症 例 数 } & 21 例 & 472例 \\
\hline \multirow{6}{*}{$\begin{array}{l}\text { 臨 } \\
\text { 症 } \\
\text { 桨 }\end{array}$} & 発熱，悪感戦傈 & $21(100 \%)$ & $414(87.7 \%)$ \\
\hline & 上愎部 痛 & 21 (1009) & $390(84.5 \%)$ \\
\hline & 黄 & $21(10096)$ & $449(95.1 \%)$ \\
\hline & $シ \quad \equiv \% \eta$ & $21(100 \%)$ & $202(42.8 \%)$ \\
\hline & 意 識 障 & $20(95.2 \%)$ & $178(37.796)$ \\
\hline & 乏 & $17(90.0 \%)$ & $135(28.6 \%)$ \\
\hline \multirow{2}{*}{ 血 } & 白血球增多 & $21(100 \%)$ & $366(77.5 \%)$ \\
\hline & リムルステスト & $5 / 11(45.5 \%)$ & $61 / 82(74.4 \%)$ \\
\hline \multirow{2}{*}{$\begin{array}{l}\text { 細培 } \\
\text { 菌躴 }\end{array}$} & 斗 & $16 / 16(100 \%)$ & $345 / 375(92.0 \%)$ \\
\hline & 血 & $4 / 11(36.3 \%)$ & $88 / 177(49.7 \%)$ \\
\hline
\end{tabular}

全国集計例ともに性別ではわずかに男性に多く，年踰も 60歳以上が過半数を占めていた．また胆道系手術の既往 をもつものが予想外に多く, 初回手術の重要性を示唆す るものと考光る．閉塞の原因としては従来の報告の如く 結石によるものが最優位を占めているが，全国集計例で 悪性腫瘍が $36.6 \%$ と比較的高率で, 感染の機会の多い ERCP 等の検査法の開発に伴って堌加していることを 考え併せ注目すべきであろう。また剖検所見に打いても 肝膿隍, ショック堅代代表される肝腎症候群も多数代認 められた，その死亡率はさんたんたる成績で，教室例で は70\%，全国例でる約半数が死亡して和り，とくに非手 
表 4 急性閉塞性化膿性胆管炎患者の統計的観察 一原因と治療成績一

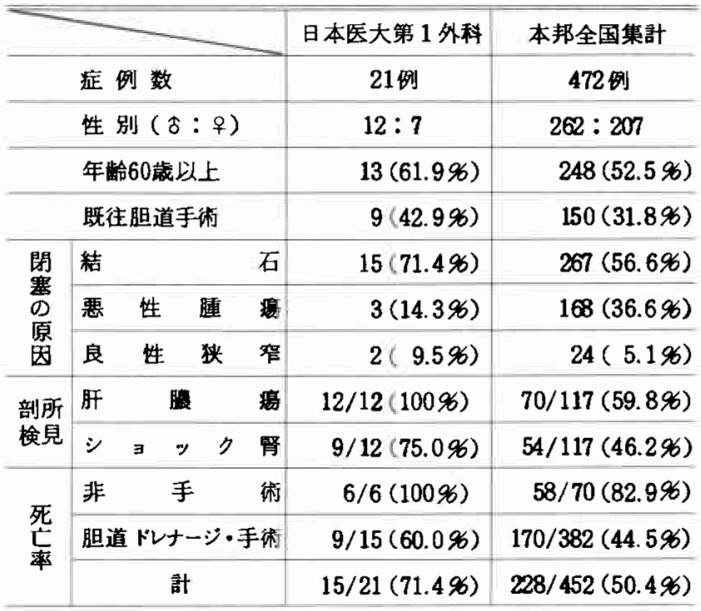

写真 1

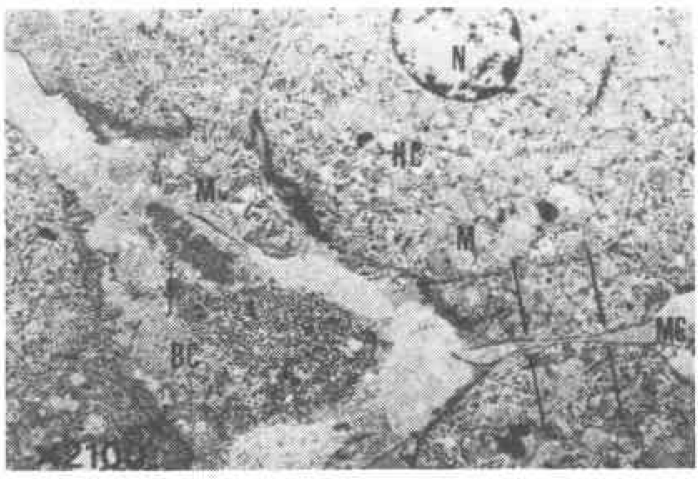

術例では教室で全例, 全国集計例です80\%以上が死亡し ておりたと著しく重篤な状態であっても PTC-D な いしは手術による胆道減圧術を施行することが重要であ ることを強く示唆している（表 4 ）.

本症に際し高頻度にみられる胆血症, 菌血症ないしエ ンドトキシン血症の成因に関しては，従来より各種の経 路が考えられているがう （5，本症剖検による肝電䫒像を みてみると，毛細胆管の抎張と Junctional complex の 解離像が認められ，本症ショックの発来には毛細胆管内 の胆汁および細菌性因子がこの間隙より血管内に直接流 れ达むことも重要な一因子となりらることを実証しえた

(军基 1 ).

3. 胆道閉塞時にみられる内因性エンドトキシン血症 の発来についての実験的研究

胆道感染症における感染経路としては, 十二指腸乳頭
図 1 総胆管閉塞ラットの生存日数

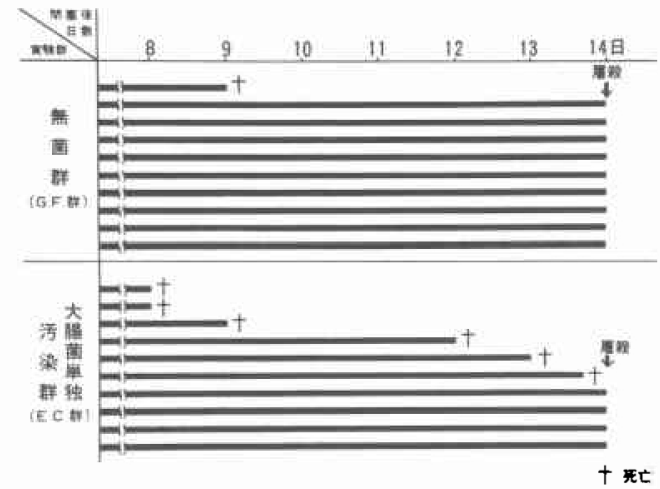

図 2 総胆管閉塞による腸管内細菌の变動 大腸菌単独污染群 $(\mathrm{n}=5)$

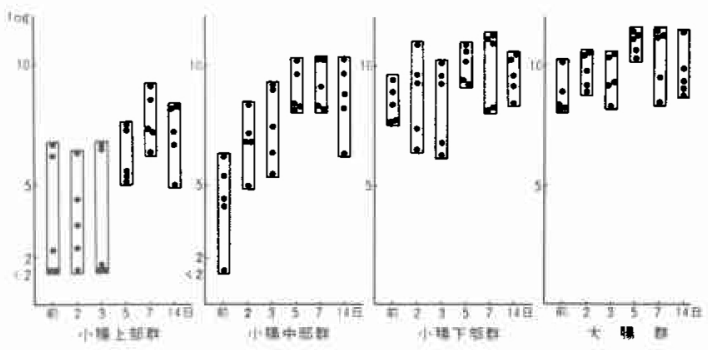

部を経由しての上行感染説が有力であるが, 近年, 腸管 内細菌由来の経門脈的細菌感染ないしは Endotoxemia がその感染経路や病態増悪因子として注目されている。

そこで今回，著者は腸管内に細菌の全く欠如する無菌 ラット(以下無菌群) と大腸菌のみを単独污染させたラ ット（以下単独污染群）の総胆管のみを二重結禁切離し て閉塞珄黄疸を作製した.

その結果，生存時間についてみると，無菌群では閉塞 14日目までに 1 例の死亡をみたのみであったのに対し， 単独污染群では10例中 6 例が死亡した（図 1).

また,この際の単独污染群に打ける腸管内大腸菌数の 変動をみてみると，小腸下部および大腸では結紮前すで に full growth の状態で結禁後も変動はみられなかった が，小腸中部では結禁 2 日目，小腸上部に执いても結禁 5 日目より著明な大腸菌数の増加を認めた。これは胆道 閉塞に伴う腸管内での胆汁欠如に起因するものと考えら れる(図2).

その際の血中エンドトキシンおよび大腸菌の検索をし てみると，リムルステスト法を用いたエンドトキシンの 検索では門脈中で結禁前すでに 2 例の陽性例を認めた 
表 5 総胆管閉塞ラットの Limulus test および細菌㭘索（大腸菌単独污染群）

\begin{tabular}{|c|c|c|c|c|c|c|}
\hline \multirow{2}{*}{ 閉弿 } & \multicolumn{2}{|c|}{ Limulus test } & \multicolumn{4}{|c|}{ 細 菌 検 索 } \\
\hline & 阴脈血 & 大動脈血 & 門脈血 & 大動脈血 & 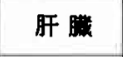 & 胆汁 \\
\hline \multirow{5}{*}{ 前 } & $(+)$ & $(-)$ & $(-)$ & $(-)$ & $((-)$ & \\
\hline & $(t)$ & $(-)$ & $(-)$ & $(-)$ & $(-)$ & \\
\hline & $(-)$ & $(-)$ & $(-)$ & $(-)$ & $(-)$ & \\
\hline & $(-)$ & $(-)$ & $(-)$ & $(-)$ & $(-)$ & \\
\hline & $(-)$ & $(-)$ & $(-)$ & $(-)$ & $(-)$ & \\
\hline \multirow{5}{*}{2 日 } & $(+)$ & $(+)$ & $(-)$ & $(-)$ & $(-)$ & $(-)$ \\
\hline & $(+)$ & $(+)$ & $(-)$ & $(-)$ & $(-)$ & $(-)$ \\
\hline & $(+)$ & $(-)$ & $(-)$ & $(-)$ & $(-)$ & $(-)$ \\
\hline & $(-)$ & $(-)$ & $(-)$ & $(-)$ & $(-)$ & $(-)$ \\
\hline & $(-)$ & $(-)$ & $(-)$ & $(-)$ & $(-)$ & $(-)$ \\
\hline \multirow{5}{*}{3 日 } & $(+)$ & $(+)$ & $(-)$ & $(-)$ & $\begin{array}{c}(+) \\
1.0 \times 10^{1}\end{array}$ & $(-)$ \\
\hline & $(+)$ & $(-)$ & $(-)$ & $(-)$ & $(-)$ & $(-)$ \\
\hline & $(+)$ & $(-)$ & $(-)$ & $(-)$ & $(-)$ & $(-)$ \\
\hline & $(+)$ & $(+)$ & $(-)$ & $(-)$ & $(-)$ & $(-)$ \\
\hline & $(-)$ & $(-)$ & $(-)$ & $(-)$ & $(-)$ & $(-)$ \\
\hline \multirow{5}{*}{5 日 } & $(t)$ & $(+)$ & $(-)$ & $(-)$ & $(-)$ & $(-)$ \\
\hline & $(+)$ & $(+)$ & $(-)$ & $(-)$ & $(-)$ & $(-)$ \\
\hline & $(+)$ & $(+)$ & $(-)$ & $(-)$ & $\begin{array}{c}(+) \\
8.0 \times 10^{2}\end{array}$ & $(-)$ \\
\hline & $(+)$ & $(+)$ & $(-)$ & $(-)$ & $(-)$ & $(-)$ \\
\hline & & & $(-)$ & $(-)$ & $(-)$ & $(-)$ \\
\hline \multirow{5}{*}{7 日 } & & $(+)$ & $(-)$ & $(-)$ & $(-)$ & $(-)$ \\
\hline & $(+)$ & $(-)$ & $(-)$ & $(-)$ & $(-)$ & $(-)$ \\
\hline & $(+)$ & $(+)$ & $(-)$ & $(-)$ & $(-)$ & $(-)$ \\
\hline & $(+)$ & $(+)$ & $(-)$ & $(-)$ & $(-)$ & $(-)$ \\
\hline & $(+)$ & $(-)$ & $(-)$ & $(-)$ & $4 \stackrel{(+)}{4 \times 10^{4}}$ & $(-)$ \\
\hline \multirow{5}{*}{14 日 } & $(+)$ & $(-)$ & $(-)$ & $(-)$ & $(-)$ & $(-)$ \\
\hline & $(+)$ & $(+)$ & $(-)$ & $(-)$ & $4.0^{(+)} \times 10^{0}$ & $(-)$ \\
\hline & $(+)$ & $(+)$ & $(-)$ & $(-)$ & $(-)$ & $(-)$ \\
\hline & $(+)$ & $(-)$ & $(-)$ & $(-)$ & $(-)$ & $(-)$ \\
\hline & & $(+)$ & $(-)$ & $(-)$ & $(-)$ & $(-)$ \\
\hline
\end{tabular}

が，結禁後は経日的に陽性例が増加し，5日目以後は全 例陽性となるばかりか, 大動脈血においても，結紮前全 く陰性であったものが結禁後は門脈血と同様に陽性例の 増加を認めた。またこの際の細菌の検索においては門脈
血, 大動脈血, 胆汁中よりは全く検出されなかったが, 肝臓中より 4 例の陽性例を認めた（衰 5 ）.

また屠殺時採取した肝扣よび堅組織内エンドトキシン の検索を Anti-endotoxin rabbit IgG peroxidase を用い 
写真 2 大腸菌単独污染群胆管結禁後 3 日目の肝組 織中におけるエンドトキシンの局在 (anti-endotoxin rabbit IgG peroxidase を用いた組織酵素抗 体法) Kupffer 細胞, sinusoidal lining cell, また は一部肝細胞の中にも著明な酵素活性を認める

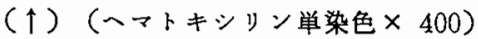

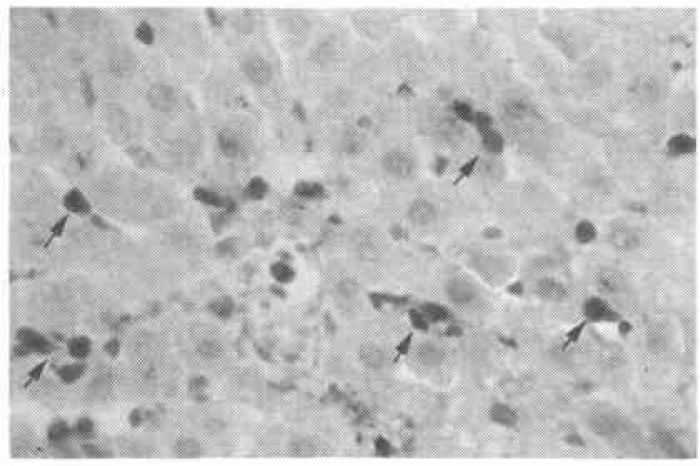

た酵素抗体法で行ってみると，肝では結禁後 3 日目，腎 では7日目に最も強い酵素活性を認めた（写交 $2 ， 3$ ）。

以上今回の研究成績は閉塞性黄疸の病態増悪因子の 1 つとしてみられる endotoxemia の発来には胆道のみな らず腸管内細菌由来の内因性エンドトキシンも強く関与 する事実の一端を明らかになしえたものと考える。

4. 胆道閉塞時にみられる内因性エンドトキシン血症 の治涼についての臨床的研究

前項でも述べた如く，胆道閉塞時には腸管内胆汁流出 障害により腸内細菌は異常に增殖する，その為腸管粘膜
写真 3 大腸菌単独污染群胆管結禁後 7 日目の腎組 織中におけるェンドトキシンの局在（anti-endotoxin rabbit IgG peroxidase を用いた組織酵素抗 体法）腫大した上皮細胞や内皮細胞，あるいは尿 細管上皮に酵素活性を認める（†）．（ヘマトキシ リン単染色 $\times 400$ )

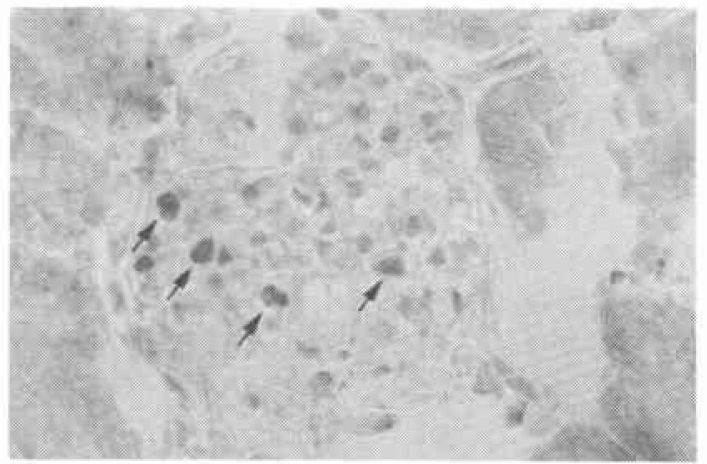

は障害され mucosal barrier の破壊をまねくと同時に, 腸内エンドトキシンの増加す相俟って内因性エンドトキ シン血症を併発しやすい.そこでこの際の治療には経口 的に胆汁成分を補給寸ると同時に非吸収性抗生物質を経 口投与し, 腸内での Bacterial Imbalance の状態を改 善することが重要であると考える.

症例 I : 69歳男子, 総胆管癌にて広範な癌侵潤と腹腔 内諸藏器に転移を認め手術不能例と判断し, PTC-D の みにて減黄していたが，268病日より突然熱発し，胆汁 中より Serratia および E. cloacaeを証明したため,

図 3 エンドトキシン血症に対する非吸収性抗生物質経口投与による治療成績

一有効 例一

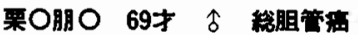

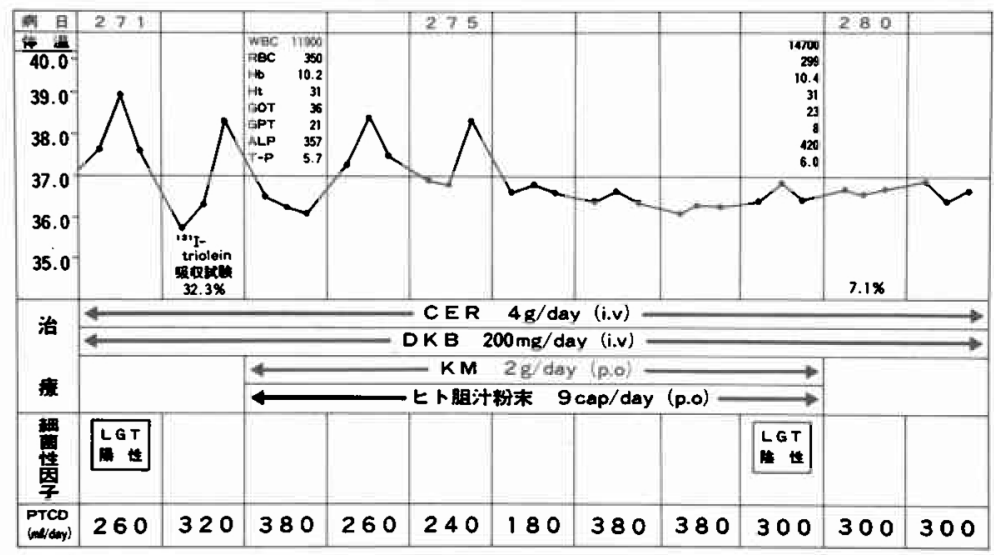


同菌感受性抗生物質 CER，4g/day および DKB，200mg/ day を経静脈的に投与するも全く下熱の傾向はみられな かったそそこで非吸収性抗生物質 $\mathrm{KM}, 2 \mathrm{~g} /$ day と教室 で精製したヒト胆汁粉末 $9 \mathrm{cap} /$ day (1 cap 中約64mg の胆 汁酸を含有)を経口投与したところ, 投与 3 日目より下 熱し，その効果は投与中止後も約 7 日間持続した. 投与 前は脂肪吸収試験の結果も悪く、リムルステストでも陽 性であったが，投与後は脂肪吸収能の著明な改善とりム ルステストる陰性となった（図３）.

図 4 エンドトキシン血症に対する非吸収性抗生物

質経口投与による治療成績

\section{一無 効 例一}

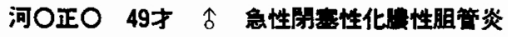

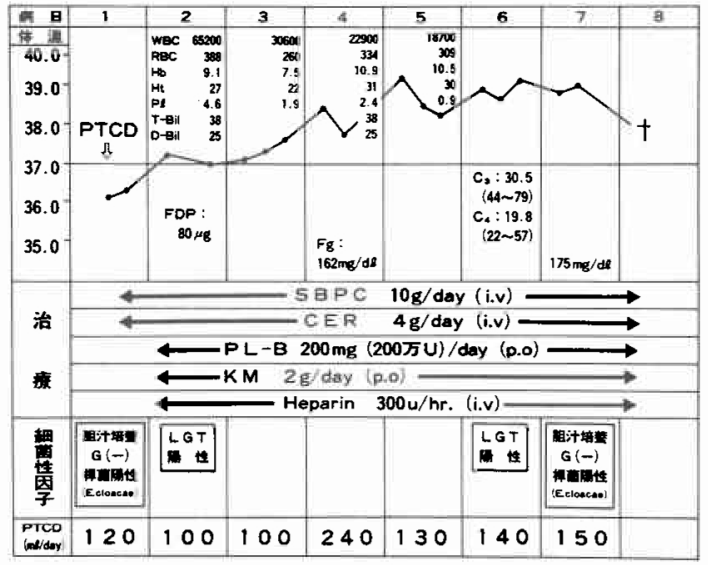

本症例に拈いては腸管内細菌由来の内因性エンドトキ シン血症を胆汁および非吸収性抗生物質経口投与で腸内 細菌巣の乱れを調整することにより改善せしめたものと 考えるが，＜図 4>の如き全く無効の例もあり，治験数 も少数なため，今後症例を選んでさらに検討して行きた いと考えている.

\section{III まとめ}

胆道系疾患にしばしばみられる合併症の一つとして朋 胆道系への感染が挙げられるが，この感染経路としては 腸内細菌が十二指腸乳頭部を越えて胆管を上行する上行 感染説, 腸内細菌が経門脈的に肝葴を経て下行する下行 感染説およびリンパ行性説などがある゙ ${ }^{6)}$.

代田らは ${ }^{10)-15)}$ 長年にわたり胆道閉塞の際の腸内細菌 巣の変動を臨床的ならびに実験的に追究し，腸管内への 胆汁流出障害により腸内細菌栄はいわゆる Dysbackterie の状態を呈し，大晹菌を中心とする腸管内細菌の上行が
みられ，胆汁中胆汁酸濃度の低下と相俟って細菌の胆道 への感染が発生するものと述べている.

そこで本稿では胆道系疾患を代表する胆石症について の教室に拈ける手術成績と死因を検討し，同疾患治療に 対する細菌感染予防の重要性を確認した。

ところで AOSC は最も重篤な胆道感染症として 1877 年に $\operatorname{Charcot}^{16)}$ により記載報告されて以来, その臨床 像は Rogers, Grant ${ }^{17)}$ らにより報告されてきたが, 1959 年 Reynords \& Dargan $^{18)}$ らはいわゆる Charcot の三徵 として知られている上腹部痛, 黄疸, 覀感発熱にさらに 精神症状とショック状態を加えて本症の五徽とし，そ の臨床的概念が漸次明らかにされ，本邦に扎いて大 浜 $^{19)}$ ，菅原 ${ }^{201}$ ，大内 ${ }^{21)}$ らとより報告されている。

そこで，わが教室例および全国集計例を基礎としてそ の臨床症状, 成因, 治療成績を検討 し, 初回胆道系手術 の重要性と近年その進歩の著しい ERCP，PTCなどの 諸検査に際し粗暴, 不潔な操作に対する戒めを再確認し た. 本症と診断が確定したら可及的早期に胆道減俚術を 施行することが重要であるが，本症剖検時の電顕像にて 供覧した如く, 本症に颃いては朋細胞間隚の解離が起こ り，細胆管内の細菌ないしはエンドトキシンが血管内に 移行しやすい状態となっているため, 胆道減王に際し造 影などによりさゃやみに胆道内圧を高めることは厳に慎むる ベさである。

ところで最近に到り，内科領域 ${ }^{22) ~ 24)}$ こ拈いても劇症 肝炎や肝硬変症などの急性ないしは慢性肝疾患などの病 態と腸管由来の経門脈的細菌性因子の関係がにわかに注 目されてきているが，門脈血中へのエンドトキシンの出 現に関してはすでに内外諸家により多数報告されてい る.

そこで腸管内に細菌の全く欠如する無菌動物を使用し て, 閉塞性黄疸時の内因性エンドトキシン血症の発来を 立証すると供に臨床例についてのその治療法について検 討し，その結果の一端も併わせ報告した。

\section{文献}

1) Hultborn, A., Jacobsson, B. and Rosengren, B. : Cholangiovenous reflux during cholangiography. Acta Chir. Scand., 123: 111-124, 1962.

2) Jacobsson, B., Kjellander, J. and Rosengren, B.: Cholangiovenous reflex. An experimental study. Acta Chir. Scand., 123: 316-321, 1962.

3) Huang, T., Bass, J.A. and Williams, R.D.: The significance of biliary pressure in chol- 
angitis. Arch. Surg., 98: 629-632, 1969.

4) 谷川久一: 肝細胞の病態. 細胞, $3: 12-21$, 1971.

5）高田忠敬，内田泰彦，磯辺孝司，他：胆道感染 症における bile-blood fistula の検討. 日消会 誌, $73: 1137,1976$.

6) 三宅 博: 胆石症. 金原出版, 東京, 1970 .

7) 䫅哲夫：肝・肥道・膵疾患の外科. 金原出 版, 東京, 1974 .

8) 佐藤寿雄ほか：胆石症々腸内細菌, 胆道感染 症. 最新医学, 33:2034-2037, 1978.

9) Scott, A.J.: Bacteria and disease of the biliary tract. Gut, 12: 487-492, 1971.

10) 代田明郎, 三樹 勝：Gram 陰性桿菌感染症一 胆道疾患，とくに胆石症を中心として一。 今日 の臨床外科, $2: 73-91,1976$.

11) 代田明郎, 三樹 勝, 吉岡正智, 他 : 急性胆管 炎の病態一とくに細菌学的研究成績を中心とし て一。臨床成人病，6:1209-1225, 1976.

12) 代田明郎, 三樹 勝: 閉塞性黄疾における肝腎 症候群の発来について。 日外会誌，78:968一 $971,1977$.

13) 三樹 勝：胆輁切除後症候群をめぐる病態一と くに胆石の再発ないし遺残と急性閉塞性化膿性 胆管炎によるショックの発来機棈を中心とし て. Medicina $13: 226-231,1976$.

14) 三樹 勝, 代田明郎, 吉岡正智, 他 : 黄㾝を伴 った胆道系疾患手術後の急性腎不全一とくに急 性閉塞性化膿性胆管炎における肝腎症候群の発 来について一. 臨外科, 31:1569-1580, 1976.

15) 三樹 睠, 代田明郎, 吉岡正智, 他: 閉塞性黄 㾝における胆道内圧の变動と肝循環動態一急性
閉塞性化膿性胆管炎における endotoxemia の 発来機構について一, 日消外学会誌, 10:715 $-723,1977$.

16) Charcot, J.M.: Lecons sur lesmaladies du foie, des voies biliaries et des reins. Paris, Faculte de Medecine de Paris, 1877, Rogers, L.: Biliary abscesses of liver with operation. Br. Med. J., 2: 706, 1903.

17) Grant, H.D.: Acute suppurative cholangitis. Permanent Eoundation Med. Bull., 3: 175, 1945.

18) Reynolds, B.M. and Dargan, E.L.: Acute obstructive cholangitis. Ann. Surg., 150: 299, -303, 1959.

19）大浜 庸：急性閉塞性化膿性胆管炎. 秋田医師 会誌, $23: 174-177,1971$.

20）菅原克彦, 田島芳雄, 玉熊正说, 他 : 胆管炎の 臨床一特に急性胆管炎を中心とした考察一, 臨 外科, $27: 1061-1070,1972$.

21) 大内清太, 小野慶一, 嶋野松朗, 他 : 急性閉塞 性化膿性胆管炎について。外科治療, $30: 469$ -479, 1974.

22) 多羅尾和郎, 他: 肝硬変症におけるエンドトキ シンについて．日消誌，73:1366一1372, 1976.

23）山本祃夫, 他 : 肝・胆道疾患に合併したエンド トキシン血症の臨床病理学的検討, エンドトキ シンの基碄と臨床. 第 1 回エンドトキシン臨床 研究会記録, 羊土社, 1979 .

24) 田井千秋, 他 : 肝疾患患者の血中エンドトキシ ンおよびその抗体価について，エンドトキシン の基礎と臨床. 第 1 回エンドトキシン臨床研究 会記録, 羊土社, 1979 . 